logos_i_ethos_2017_2_(46), s. 129-153

DOI: http://dx.doi.org/10.15633/lie.2365

Rafał S. Niziński

Uniwersytet im. Adama Mickiewicza w Poznaniu

\title{
Racjonalność czy rozumność: próba zmiany paradygmatu filozoficznego poznania Boga - myśl Xaviera Zubiriego
}

Jednym ze spotykanych zarzutów wobec klasycznych dowodów na istnienie Boga, mam tu na myśl np. dowody Tomasza z Akwinu, jest to, że „udowodniony” Bóg nie jest Bogiem religii, lecz Bogiem filozofii. Prowadzi to do sytuacji, w której otrzymany obraz Boga nie zachęca do wejścia z Nim w relację, czyli nie zachęca do wiary religijnej. Zadanie znalezienia drogi do Boga, w ramach której

Rafał S. Niziński - adiunkt w Zakładzie Filozofii Chrześcijańskiej UAM. Zajmuje się filozofią Boga, a w związku z tym także metafizyką i epistemologią. W dotychczasowym studium zajmował się: metafizyką M. Heideggera, filozofią Boga Ch. Hartshorne’a, teologią $\mathrm{K}$. Bartha - problem racjonalności wiary, filozofią Boga X. Zubiriego (obecna dziedzina badań), mistyką karmelitańską św. Jana od Krzyża oraz św. Teresy od Jezusa oraz filozofią mistyki. Opublikował kilka pozycji książkowych, artykułów oraz prac pod swoją redakcją. otrzymany taki Jego obraz, który będzie spełniał rolę religijnego, jak i filozoficznego obrazu, stawiali sobie różni myśliciele ${ }^{1}$. Do tego nurtu dołącza Xavier Zubiri ${ }^{2}$. Aby to osiągnąć, Zubiri przedstawia własny paradygmat poznania Boga. Uważa on, że to nie racjonalność prowadzi do poznania Boga, tylko rozumność. Jeśli poznanie racjonalne jest zawężone do wysiłków czysto intelektualnych, to rozumność, według Zubiriego, jest pojęciem szerszym i włączającym poznanie racjonalne. Rozumność otwiera się na wolę oraz uczucia i przypisuje im pewną rolę poznawczą.

1 Por. Ch. Hartshorne, Man's Vision of God and the Logic of Theism, Connecticut 1964, s. IX; M. Jędraszewski, Bóg filozofów i Bóg Jezusa Chrystusa, Poznań 2011, s. 65-70.

2 X. Zubiri, El problema filosófico de la historia de las religiones, Madrid 2006, s. 40, 55; zob. F. Llenín Iglesias, La realidad divina. El problema de Dios en Xavier Zubiri, Oviedo 1990, s. 106. 
W związku z powyższym postulatem Zubiriego zasadne jest pytanie, czy rzeczywiście pojęcie Boga zaprezentowane przez tego filozofa pozwala Bogu na bycie jednocześnie Bogiem filozofii, jak i religii. A także, czy metoda poznania Boga zaproponowana przez Zubiriego może funkcjonować również poza jego filozofią?

Ponieważ Zubiriego sposób dotarcia do Boga powinien spełniać podwójną rolę, otrzymane pojęcie Boga powinno spełniać pewne standardy myślenia racjonalnego, a jednocześnie powinno zachęcać do wejścia, $\mathrm{z}$ tak ukazanym Bogiem, w relację religijną ${ }^{3}$.

\section{Niewystarczalność dowodów metafizycznych}

Na początku Zubiri podaje powody, dla których dotychczasowe dowody metafizyczne nie spełniły swojej roli. Filozof wprost odnosi się do klasycznych dowodów św. Tomasza z Akwinu4. Wysuwa przeciw nim kilka zarzutów.

Pierwszy zarzut mówi o tym, że punkt wyjścia tych dróg jest poprzedzony pewną teorią. Tymczasem Bóg, którego mamy poznać, nie ma być Bogiem jakiejś teorii, lecz Bogiem rzeczywistości ${ }^{5}$. Zarzut ten jest zgodny z fenomenologicznym paradygmatem poznania, do którego nawiązuje Zubiri ${ }^{6}$. Jego zdaniem pierwsza droga Tomasza mówi nie o ruchu, lecz o przejściu z możności do aktu, co nie jest faktem, ale już jakąś interpretacją ruchu. Druga droga wydaje się wątpliwa ze względu na to, że tylko człowiek może być przyczyną sprawczą. Pozostałe przypadki to wyłącznie regularne następstwa zdarzeń. Mówienie, że w jakichś okolicznościach działa przyczyna sprawcza, jest już interpretacją doświadczenia. W trzeciej drodze faktem dla Tomasza jest jednocześnie to, że rzeczy powstają i znikają, czyli faktem miałaby być ich niekonieczność istnienia. Zubiri to odrzuca, gdyż to, co możliwe i konieczne, nie jest dane w doświadczeniu.

3 Zob. X. Zubiri, El hombre y Dios, Nueva edición, Madrid 2012, s. 246-247.

4 Thomae Aquinatis, Summa theologiae, Matritii 1978, I, q. 2, a. 3.

5 Zob. X. Zubiri, Inteligencia y razón, Madrid 2008, s. 15, 32, 82.

6 Zob. X. Zubiri, El problema filosófico de la historia..., dz. cyt., s. 288-289, 294. 
Tak samo w doświadczeniu nie jest dana kontyngencja wszystkich bytów. W podobny sposób Zubiri krytykuje także pozostałe drogi Tomasza ${ }^{7}$. Hiszpański filozof nie polemizuje z Tomaszem co do słuszności konkluzji, jaką jest na przykład istnienie aktu czystego, lecz z tym, że Tomasz rozmija się z deklaracją wychodzenia od faktów.

Drugi zarzut wobec powyższych dróg dotyczy konkluzji, do jakich dochodzi Tomasz. Pięć różnych wniosków niekoniecznie musi oznaczać jeden i ten sam byt, którym jest Bóg. Aby tak było, trzeba by to wpierw wykazać 8 .

Zagadnieniem otwartym pozostaje także trzeci zarzut: czy najwyższy byt (ente supremo) jest Bogiem? Zubiri przypomina rozważania Dunsa Szkota dotyczące tego zagadnienia ${ }^{9}$. W drugiej części swojego dowodu Szkot chce wykazać, że dowiedziony przez niego pierwszy byt sprawczy jest nieskończony, co oznacza, że jest Bogiem, gdyż dla Szkota atrybutem Boga jest nieskończoność. W związku z tym Zubiri stawia pytanie, czy to, co jest nieskończone, musi być Bogiem. Sam Zubiri odrzuca taką koncepcję. Według niego Szkot szuka tylko istoty metafizycznej - według terminologii scholastycznej - a nie Boga ${ }^{10}$. Dlatego Tomaszowy najwyższy byt jako akt czysty, czy też byt konieczny to jedynie pojęcia najdoskonalszych bytów, co jeszcze nie oznacza Boga.

\section{Etap racjonalny drogi do Boga}

\section{Niewłaściwy punkt wyjścia?}

Zubiri, szukając właściwego punktu wyjścia pozwalającego dojść do poznania Boga, zauważa, że musi być nim człowiek, a konkretnie osoba ludzka. Czyniąc z człowieka punkt wyjścia, zaznacza, że nie można do niego podejść w dowolny sposób. Jako przykład pobieżnie przytacza

7 Zob. X. Zubiri, El hombre y Dios, dz. cyt., s. 136-138.

8 Zob. X. Zubiri, El hombre y Dios, dz. cyt., s. 139.

9 Por. F. T. Janka, Jana Dunsa Szkota dowód na istnienie Boga, w: Primum philosophari. Opuscula Antonio Siemianowski dedicata, Poznań 2016, s. 123-132.

10 Zob. X. Zubiri, El hombre y Dios, dz. cyt., s. 139-140. 
antropologiczne drogi odkrywania Boga, którymi przeszli inni filozofowie. I tak, analizuje dowód św. Augustyna wychodzącego, zdaniem Zubiriego, od prawdy skończonej, którą poznaje człowiek, a która to prawda ma prowadzić do prawdy całkowitej ${ }^{11}$. Następnie przedstawia dowód Immanuela Kanta mówiącego o woli, która kategorycznie powinna chcieć ze względu na obowiązek, co wymaga istnienia dobra samego w sobie ${ }^{12}$. Na końcu wspomina dowód Friedricha Schleiermachera wychodzącego od uczucia bezwarunkowej zależności od nieskończoności. Jest to uczucie dotyczące rzeczywistości irracjonalnej i nieskończonej ${ }^{13}$. W konsekwencji te trzy dowody opierające się na analizie ludzkiej inteligencji, woli i uczucia prowadziłyby w zamyśle ich autorów do samodzielnej prawdy, doskonałego dobra oraz rzeczywistości nieskończonej, czyli Boga ${ }^{14}$.

Zubiri wątpi w to, że wspomniane trzy aspekty człowieka, od których wychodzą te dowody, są rzeczywiście faktami. Poza tym ujmują człowieka tylko częściowo. Tymczasem człowieka należy ująć całościowo. Trzeci zarzut: wszyscy ci myśliciele przyjmują dualistyczną wizję człowieka ${ }^{15}$. Stąd punkt wyjścia drogi do Boga jest już zdeterminowany pewną wizją człowieka, w której człowiek jest w opozycji do rzeczywistości. W konsekwencji otrzymuje się obraz Boga odseparowanego od świata. Choć ci trzej autorzy chcą integracji Boga ze światem i rzeczywiście integrują Go ze światem, to jednak konieczność tej integracji jest najbardziej doskwierającym mankamentem ich dowodów. Tak pojęty Bóg jest odseparowany od świata, a złączony jedynie z człowiekiem. Częściowość tych trzech aspektów człowieka, ich wewnętrzny dualizm, opozycja Boga w stosunku do kosmosu - to według Zubiriego mankamenty omawianych dowodów ${ }^{16}$.

11 Augustyn w swoim dowodzie przechodzi od poznania prawd niezmiennych i koniecznych do Boga, który jest prawdą najwyższą. Zob. Augustyn z Hippony, O wolnej woli, tłum. A. Trombala, w: Augustyn z Hippony, Dialogi filozoficzne, Kraków 1999, ks. II, VIIInn.

12 I. Kant, Krytyka praktycznego rozumu, tłum. J. Gałecki Warszawa 1972, s. 201-202, 256-257.

13 Por. M. Potępa, Obraz człowieka w hermeneutyce Schleiermachera, "Analiza i Egzystencja” 19 (2012), s. 126.

14 Zob. X. Zubiri, El hombre y Dios, dz. cyt., s. 141.

15 Zob. X. Zubiri, El hombre y Dios, dz. cyt., s. 142-143.

16 Zob. X. Zubiri, El hombre y Dios, dz. cyt., s. 142-143. 


\section{Jaki powinien być właściwy punkt wyjścia?}

Zubiri stwierdza, że właściwa droga do Boga powinna się zaczynać od momentu, w którym mamy do czynienia $\mathrm{z}$ takim charakterem działania rzeczywistości, w którym ta przejawia bycie czymś ostatecznym ${ }^{17}$. Ma to miejsce w tworzeniu (modulowaniu) ludzkiego Ja. Stąd pierwszym krokiem będzie zagłębienie się w to, jak Zubiri rozumie człowieka i osobę.

Myśliciel odrzuca pojęcie bytu i substancji. Dla niego każda rzecz (osoba) to rzeczywistość o pewnych cechach. Samo pojęcie rzeczywistości ma dla Zubiriego kilka znaczeń: rzeczywistość konkretnej rzeczy, rzeczywistość jako zbiór wszystkich rzeczy oraz rzeczywistość jako fundament rzeczy. Rzeczywistość w ostatnim znaczeniu to Bóg, który jest istotowo obecny w każdej rzeczy (wykazanie Jego istnienia i poznanie Jego natury jest celem, do którego zmierza droga poznania Boga, którą teraz analizujemy).

Zubiri nazywa człowieka rzeczywistością substantywną (realidad sustaniva) osobową. Jako osoba posiada samego siebie. Osoba poprzez swoje akty dokonuje autoafirmacji, przez co kształtuje swoją osobowość, czyli Ja. Zubiri zaznacza, że Ja (osobowość) nie jest osobą tylko byciem (el ser) osoby, a bycie osoby to jej pewne znajdowanie się w świecie, czyli odnoszenie się do rzeczywistości zewnętrznej względem osoby (rzeczywistości rzeczy i innych osób). Osoba, konfigurując swoje bycie, czyli odnosząc się do zewnętrznej względem siebie rzeczywistości, zmienia to bycie, co umożliwia jej życie osobowe ${ }^{18}$. Osobowość jest „pewnym sposobem bycia, jest postacią tego, co rzeczywistość ludzka czyni z siebie w ciągu całego swojego życia"19. Ważne jest uchwycenie zależności życia osobowego od rzeczywistości zewnętrznej względem osoby. Bez tej rzeczywistości nie byłoby życia osobowego.

17 „Si en la realidad descubrimos alguna dimensión que de hecho envuelva constitutiva y formalmente un enfrentamiento inexorable con la ultimidad de lo real, esto es, con lo que de una manera meramente nominal y provisional podemos llamar Dios" (X. Zubiri, El hombre y Dios, dz. cyt., s. 5-6); por. A. Ferraz Fayos, Zubiri: el realismo radical, Madrid 1988, s. 200.

18 Zob. X. Zubiri, El hombre y Dios, dz. cyt., s. 300-301.

19 M. Jagłowski, Realizm transcendentalny Xaviera Zubiriego, Olsztyn 2000, s. 183-184. 
Powyższe można wyrazić inaczej. Zubiri uznaje, że człowiek nie jest rzeczywistością (realidad) uczynioną raz na zawsze, tylko tworzy się w precyzyjny sposób. Z jednej strony człowiek jest własną rzeczywistością (realidad „suya”). Bycie własną rzeczywistością to posiadanie samego siebie, i to właśnie czyni nas osobą (persona). $Z$ drugiej strony człowiek znajduje się naprzeciw całej rzeczywistości, która nie jest jego własną rzeczywistością i jest wobec niego zewnętrzna. W tym sensie można powiedzieć, że osoba jest wolna/oddzielona (está „suelta” de toda otra realidad) od całej innej rzeczywistości: jest absolutna („ab-soluta”). Jednak absolutność osoby jest względna, gdyż jest uzyskana/otrzymana (cobrada). Co Zubiri ma na myśli, mówiąc, że osoba jest absolutem względnym (relativamente absoluto)? Osoba w aspekcie swojej osobowości tworzy się, modelując własną rzeczywistość. Dokonuje się to przez każde nowe odniesienie się człowieka do czegoś wobec niego zewnętrznego ${ }^{20}$.

Oddziaływanie rzeczywistości zewnętrznej wobec osoby polega na umożliwianiu osobie przemiany jej własnej rzeczywistości, czyli konfigurowania Ja. To właśnie w tym miejscu pojawia się ostateczny charakter działania rzeczywistości zewnętrznej wobec osoby. Zubiri zauważa, że konfigurowanie ludzkiego Ja dokonuje się dzięki rzeczom. Pisze, że człowiek dzięki rzeczom ${ }^{21}$ konfiguruje bycie własnej rzeczywistości substantywnej, czyli tworzy własne Ja, bo się zawsze wobec nich jakoś znaduje. Człowiek żyje i tworzy swoje bycie dzięki rzeczywistości (desde la realidad). To rzeczywistość przymusza człowieka do ciągłego konfigurowania Ja. Tak samo rzeczywistość jest dla człowieka ostatecznym (último) oparciem w konfigurowaniu Ja. Rzeczywistość odgrywa taką rolę wobec Ja z racji własnej realności, a nie z powodu cech poszczególnych rzeczy, które tę rzeczywistość stanowią ${ }^{22}$.

Terminologia Zubiriego w kwestii osoby jest skomplikowana. Ważne jest uświadomienie sobie, że terminy „osobowość” oraz „Ja” są bliskoznaczne i że życie osoby jako osoby polegające na przemianie osobowości

20 Zob. X. Zubiri, El hombre y Dios, dz. cyt., s. 7.

${ }^{21}$ "desde las cosas va a configurar el ser de su propia realidad sustantiva”.

22 Zob. X. Zubiri, El problema filosófico de la historia..., dz. cyt., s. 38-40. 
jest konfigurowaniem bycia osoby dzięki rzeczywistości zewnętrznej wobec osoby ${ }^{23}$. Życie osobowe to „uzyskiwanie osobowości [Ja]. Dokonuje się to w każdym akcie osoby. Polega ono na uzyskiwaniu przez osobę pewnej formy rzeczywistości”"24.

Zubiri zauważa, że rzeczywistość ma jakąś władzę nad osobą, zmieniając jej Ja. Władzę tę nazywa władzą rzeczywistości. Natomiast religacja to zależność osoby w jej życiu osobowym od rzeczywistości wobec niej zewnętrznej ${ }^{25}$. Władza rzeczywistości, do której osoba jest religowana, ustanawia fundament, czyli podwalinę życia osobowego. Mówiąc inaczej, dzięki rzeczywistości osoba może się spełniać jako osoba, gdyż tylko rzeczywistość zewnętrzna wobec osoby pozwala jej uzyskiwać nową postać bycia, a to stanowi życie osobowe ${ }^{26}$. Jeden $\mathrm{z}$ komentatorów ujmuje to $\mathrm{w}$ ten sposób: cechą specyficznie ludzką jest samoposiadanie, co czyni człowieka osobą. Osoba się afirmuje dzięki swojemu odniesieniu do innych rzeczy oraz do siebie samej. Człowiek nie jest poza rzeczywistością ani nie czyni siebie samego, odnosząc się tylko do siebie samego, lecz musi czynić siebie samego w rzeczywistości wraz z innymi rzeczami realnymi ${ }^{27}$.

Zubiri nie zgadza się z opinią, że odnoszenie się do rzeczywistości zewnętrznej wobec osoby jest tylko aktem psychicznym ${ }^{28}$. Jest czymś znaczenie ważniejszym - ma konsekwencje metafizyczne, umożliwiając tworzenie $\mathrm{Ja}^{29}$. Ja, czyli bycie osoby, ma charakter metafizyczny ${ }^{30}$. To właśnie w tych okolicznościach mamy do czynienia z ostatecznościowym charakterem działania rzeczywistości wobec człowieka. To, że rzeczywistość staje się czymś ostatecznym dla człowieka, sugeruje, że w tym przejawie jej działania możemy mieć do czynienia z Bogiem.

23 Zob. X. Zubiri, El hombre y Dios, dz. cyt., s. 145-147.

${ }_{24}$ M. Jagłowski, Realizm transcendentalny..., dz. cyt., s. 186.

25 Zob. X. Zubiri, El hombre y Dios, dz. cyt., s. 8.

26 Zob. X. Zubiri, El hombre y Dios, dz. cyt., s. 89-91, 155; D. Gracia, El tema de Dios en la filosofía de Zubiri, „Estudios Eclesiásticos” 56 (1981) núm. 216-217, s. 74.

27 Por. A. Pintor-Ramos, Religación y „prueba” de Dios en Zubiri, „Razón y Fe” 218 (nov. 1988) núm. 1081, s. 324-325.

28 Zob. X. Zubiri, El hombre y Dios, dz. cyt., s. 59-60.

29 Zob. X. Zubiri, El hombre y Dios, dz. cyt., s. 83.

30 Zob. X. Zubiri, El problema filosófico de la historia..., dz. cyt., s. 35. 
Istotną kwestią jest to, że według Zubiriego religacja jest faktem ${ }^{31}$. Bycie faktem oznacza, że religacja to nie jakaś teoria, gdyż zależność bycia osoby od rzeczywistości jest oczywista, bo wszyscy jej doświadczamy. Cała moja rzeczywistość osobowa we wszystkich swych wymiarach jest religowana do władzy rzeczywistości ${ }^{32}$. Owszem, to ja tworzę nową postać mojej osoby poprzez moje odniesienie do rzeczywistości, ale bez rzeczywistości zewnętrznej wobec mnie nie byłbym w stanie tego osiągnąć. Zależność od rzeczywistości i władzy, jaka w niej spoczywa, jest we wszystkich rzeczach. Tylko w przypadku człowieka, z racji dominacji nad ludzką osobą, to działanie dotyka ludzkiej inteligencji i tylko człowiek ma dostęp do tego działania niejako od środka, bo doświadczając go w samym sobie ${ }^{33}$. Jest tak, ponieważ ze względu na akty inteligencji osoba konfiguruje swoje bycie ${ }^{34}$. Właśnie to pozwala mieć niepoprzedzony żadną wcześniejszą teorią dostęp (accesible a un análisis inmediato) do zależności między osobą a rzeczywistością (a w konsekwencji do zależności od Boga). W filozofii Tomasza stwarzanie bytów i ich poruszanie jest już, zdaniem Zubiriego, jakąś interpretacją rzeczywistości, a nie faktem. Nie mamy bowiem doświadczenia przyczyny sprawczej lub przyczyny ruchu, obserwujemy tylko następstwo zdarzeń. To dlatego Tomasz jest w błędzie, zaczynając swoją drogę do Boga od jakichś aspektów rzeczywistości niezwiązanych z człowiekiem - uważa Zubiri. Tak samo błędna jest droga, którą przemierzyli św. Augustyn i inni, gdyż nie ujęli człowieka w tym, co czyni go zależnym ostatecznościowo (całościowo) od rzeczywistości, bo tylko dla osoby rzeczywistość jest czymś ostatecznym. Zubiri podsumowuje te wywody, stwierdzając, że ostatecznościowe (la ulterioridad) działanie rzeczywistości ukazuje się w modelowaniu bycia osoby ${ }^{35}$. Z drugiej strony rozpoczęcie rozważań od pojęcia religacji sprawia, że nie będziemy mieli do czynienia z Bogiem, który jest

31 Zob. X. Zubiri, El hombre y Dios, dz. cyt., s. 272.

${ }^{32}$ Zob. X. Zubiri, El hombre y Dios, dz. cyt., s. 145-147.

${ }_{33}$ Zob. X. Zubiri, El hombre y Dios, dz. cyt., s. 22-23. Zob. X. Zubiri, El hombre y Dios, dz. cyt., s. 30 .

${ }_{34}$ Zob. X. Zubiri, El hombre y Dios, dz. cyt., s. 6, 151; F. Llenín Iglesias, La realidad divina..., dz. cyt., s. 100 .

35 Zob. X. Zubiri, El hombre y Dios, dz. cyt., s. 148-149. 
tylko wyjaśnieniem jakiegoś procesu w świecie bytów, lecz z Bogiem, który umożliwia nawiązanie z Nim relacji religijnej, gdyż jest odpowiedzialny w całości za życie osobowe człowieka ${ }^{36}$.

$\mathrm{Na}$ jakiej podstawie mamy prawo przypuszczać, że władza rzeczywistości wobec Ja daje możliwość dotarcia do Boga? Wynika to z przeprowadzonej wyżej analizy charakteru działania rzeczywistości. Władza rzeczywistości ma wyjątkowy i szczególny charakter (supremo) w stosunku do ludzkiej osoby, gdyż jest fundamentem konstytucji mojego Ja ${ }^{37}$. Ponadto rzeczywistość jest czymś, co stwarza osobie możliwości wyboru tej czy innej formy bycia. Rzeczywistość uniemożliwia także bierność, bo przymusza osobę do zajęcia jakiegoś stanowiska wobec niej ${ }^{38}$. To właśnie te trzy cechy dominacji rzeczywistości nad osobą stwarzają podstawy do przypuszczenia, że w tym momencie mamy do czynienia z przejawem (przynajmniej nominalnym) działania Boga. Co więcej, religacja w tych trzech cechach sugeruje profil idei Boga ${ }^{39}$.

Podsumowując ten etap argumentacji odnoszącej się poznania Boga, mamy jakieś podstawy przypuszczać, że Bóg to właśnie owa rzeczywistość, która stoi u podstaw tych trzech cech działania rzeczywistości wobec osoby. Dlaczego ta rola rzeczywistości wobec Ja domaga się istnienia Boga? Ponieważ właśnie takie działanie rzeczywistości wobec Ja jest problematyczne (enigmatico), to znaczy nie jest wyjaśnione tym, czym rzeczy (jako rzeczywistość nie moja) są. Z tego powodu Zubiri stwierdza, że każda rzecz jest własną rzeczywistością (su realidad) oraz obecnością innej rzeczywistości (,la” realidad). Rzeczy mają bowiem pewną moc wobec osoby, której nie można wytłumaczyć ich własną rzeczywistością (su realidad). Potrzebują czegoś, co je do tego uzdalnia i tym czymś ma być ich fundament znajdujący się w nich samych ${ }^{40}$. Gdy nie wiemy, co jest tym fundamentem, tworzenie

36 Zob. X. Zubiri, El hombre y Dios, dz. cyt., s. 205.

37 Zob. X. Zubiri, El hombre y Dios, dz. cyt., s. 149.

38 Zob. X. Zubiri, El hombre y Dios, dz. cyt., s. 89-91.

39 Zob. X. Zubiri, El hombre y Dios, dz. cyt., s. 147-148; G. Díaz Muńoz, Búsqueda de Dios en el misterio según X. Zubiri, „Estudios Eclesiásticos” 84 (2009) núm. 328, s. 148.

40 Zob. X. Zubiri, El hombre y Dios, dz. cyt., s. 162-164; X. Zubiri, Inteligencia y razón, dz. cyt., s. 63-64; J. Sáez Cruz, La accesibilidad de Dios: su mundanidad y transcendencia en X. Zubiri, 
ludzkiego Ja jest problematyczne. Bóg zatem powinien być fundamentem władzy rzeczywistości, czyli musi umożliwiać (wyjaśniać) religację ${ }^{41}$. Dlatego powinien być fundamentem ostatecznym, stwarzającym możliwości i pobudzającym dla tworzącego się Ja. Tak zarysowany obraz Boga jest na razie jedynie pewną ideą Boga jako Boga ${ }^{42}$. Jeśli zatem istnieje Bóg, to będzie On rzeczywistością, która jest fundamentem osoby oraz rzeczy, gdyż tworzenie Ja jest możliwe jedynie przez kontakt z rzeczami ${ }^{43}$.

Powyższe sformułowania nasuwają wątpliwość, czy religacja ma rzeczywiście charakter aż tak głęboko metafizyczny, czyli czy nie mamy do czynienia w tym momencie raczej z powierzchowną przemianą? Tworzenie Ja, o którym wspomina Zubiri, nie jest bowiem stwarzaniem „od zera”, tylko przemianą czegoś wcześniej rzeczywistego. Mieczysław Jagłowski precyzuje: „Ponieważ osoba jest czymś aktualnym (rzeczywistym), personalizacja jako nowy, drugi akt, jako reaktualizacja jest aktem samopotwierdzenia się osoby jako identycznej ze sobą samą" ${ }^{44}$. Na postawione pytanie Zubiri mógłby odpowiedzieć, że bez dominacji rzeczywistości wobec Ja nie byłoby życia osobowego, które należy do istoty człowieka ${ }^{45}$. Ponieważ rzeczywistość z racji swojej realności funduje moją rzeczywistość osobową, jej dominacja wobec Ja nie jest czymś powierzchownym, lecz ma charakter ostatecznościowy, czyli bez jej fizycznej dominacji nie byłoby mojego $\mathrm{Ja}^{46}$. Religacja musi mieć zatem charakter metafizyczny, istotny dla życia osobowego.

\section{Postulowanie fundamentu rzeczywistości}

Określiliśmy tym samym, jaki powinien być punkt wyjścia w drodze do poznania Boga. Jest nim władza rzeczywistości nad ludzką osobą,

Salamanca 1995, s. 215; F. Llenín Iglesias, La realidad divina..., dz. cyt., s. 107-108; A. PintorRamos, Dios y el problema de la realidad en Zubiri, „Cuadernos de Pensamiento” 1987 núm. 1, s. 113.

${ }_{41}$ Zob. X. Zubiri, El hombre y Dios, dz. cyt., s. 165

${ }^{42}$ Zob. X. Zubiri, El hombre y Dios, dz. cyt., s. 148.

43 Zob. X. Zubiri, El hombre y Dios, dz. cyt., s. 149.

44 M. Jagłowski, Realizm transcendentalny..., dz. cyt., s. 186. Jagłowski mówi w tym wypadku o „quasi-kreacji” (s. 173); por. A. Pintor-Ramos, Religación y..., dz. cyt., s. 325-326.

45 Zob. X. Zubiri, El hombre y Dios, dz. cyt., s. 145-157.

46 Zob. X. Zubiri, El hombre y Dios, dz. cyt., s. 93-94. 
która domaga się wyjaśnienia. Rzeczy same w sobie nie ukazują tego, co je uzdalnia do posiadania takiej władzy. Niemniej, co jest ważne, coś sugerują ze względu na sposób swojego oddziaływania na osobę. Jak można przejść od tego problemu do jego wyjaśnienia? Można by powiedzieć, przeprowadzając analogię do dowodu z ruchu Tomasza z Akwinu, że znajdujemy się w momencie, gdy Tomasz sobie uświadamia, że rzeczy, z którymi mamy kontakt, nie wyjaśniają przykładowo ruchu w kosmosie, dlatego postuluje on istnienie aktu czystego, wyjaśniającego istnienie ruchu w świecie. Za każdym razem przejście od przesłanek do wniosku $\mathrm{w}$ drogach Tomasza jest jednoznaczne w tym sensie, że punkt wyjścia każdego z tych dowodów dotyczy jednego precyzyjnego aspektu rzeczywistości. W przypadku drogi Zubiriego tak nie jest, gdyż nie jesteśmy w stanie wskazać jednoznacznie, jaki powinien być fundament rzeczywistości. Dlaczego? W przypadku ruchu kwestia wydaje się być oczywista, gdyż jeśli nie przyjmiemy istnienia aktu czystego, ruch będzie niezrozumiały. Natomiast w przypadku tworzenia Ja, zdaniem Zubiriego, nie ma wyraźnej sugestii co do natury fundamentu rzeczywistości ${ }^{47}$. Fundament, choć obecny w rzeczach i realnie przez nie oddziałujący, jest dla nas niewidoczny ${ }^{48}$. Rzeczy są jedynie jego rezonatorami, rysując jego profil $^{49}$. Rzeczywistość co najwyżej sugeruje pewien kierunek w poszukiwaniu fundamentu ${ }^{50}$. Kierunek ten wyznaczają wspomniane trzy cechy dominacji rzeczywistości nad osobą, ale jest to sugestia dość ogólna ${ }^{51}$. Świadczy o tym doskonale historia religii, która jest świadectwem szukania fundamentu ${ }^{52}$.

Jaki zatem powinien być kolejny krok w drodze do odkrycia Boga? Ponieważ nie ma bezpośredniego przejścia od dominacji rzeczywistości

47 Zob. X. Zubiri, El hombre y Dios, dz. cyt., s. 244; X. Zubiri, Inteligencia y razón, dz. cyt., s. 107.

48 Zob. X. Zubiri, El problema filosófico de la historia..., dz. cyt., s. 59-60, 293-294; M. Jagłowski, Realizm transcendentalny..., dz. cyt., s. 111.

49 Zob. X. Zubiri, El problema filosófico de la historia..., dz. cyt., s. 304.

${ }_{50}$ Zob. X. Zubiri, El hombre y Dios, dz. cyt., s. 200, 244-244; X. Zubiri, Inteligencia y razón, dz. cyt., s. 22-23.

${ }_{51}$ Zob. X. Zubiri, El hombre y Dios, dz. cyt., s. 10; X. Zubiri, Inteligencia y razón, dz. cyt., s. 62.

52 Por. E. Solari, La raíz de lo sagrado. Contribuciones de Zubiri a la filosofía de la religión, Santiago de Chile 2010, s. 356-357. 
do jej fundamentu, obraz fundamentu musi być wymyślony przez człowieka. Potrzebny jest szkic fundamentu, bo bez tego szkicu nie będziemy wiedzieli, czego szukamy ${ }^{53}$. Jednak mimo pewnych sugestii co do fundamentu rzeczywistości, tworzenie szkicu jej fundamentu jest dowolne $e^{54}$.

Systematycznej rekonstrukcji opisu szkicowania obrazu Boga, jakiego dokonuje Zubiri, podejmuje się Jesús Sáez Cruz. Zubiri proponuje szkic, który uwzględnia wspomniane wcześniej cechy człowieka jako rzeczywistości względnie absolutnej, fizycznie zależnej od władzy rzeczywistości, która wobec Ja jest czymś ostatecznym, dającym możliwości i przymuszającym. Według Zubiriego szkicowany obraz Boga powinien tłumaczyć i umożliwiać te fakty. Dlatego Bóg powinien być rzeczywistością ostateczną, źródłem możliwości wyboru form realizacji życia osobowego człowieka, siłą przymuszającą człowieka do wybierania ${ }^{55}$. Bóg powinien być osobowy, aby umożliwić nam życie osobowe i wejście z nim w relację osobową $\mathrm{z}$ wdzięczności za to, że możemy żyćs ${ }^{56}$. Stąd powinien być rzeczywistością „absolutnie absolutną," będącą elementem konstytutywnym rzeczywistości i przenoszonej przez nią władzy obecnej w każdej rzeczy ${ }^{57}$. Realna obecność Boga w rzeczach powinna być tego rodzaju, że każda rzecz jest konstytuowana „w” Bogu, a Bóg jest obecny „w” niej. Rzeczy powinny być boskim życiem ad extra w jego formie skończonej. Innymi słowy, rzeczy powinny być projekcją Boga ad extra ${ }^{58}$. Kolejnym etapem szkicowania jest dedukcja, która wychodzi od rozumienia Boga jako rzeczywistości absolutnie absolutnej. Bóg (w sobie) powinien być rzeczywistością odrębną od istniejących rzeczy, będąc absolutem z siebie

53 Zob. X. Zubiri, El problema filosófico de la historia..., dz. cyt., s. 296; X. Zubiri, Inteligencia y razón, dz. cyt., s. 220-221.

${ }_{54}$ Zob. X. Zubiri, Inteligencia y razón, dz. cyt., s. 109, 147-148, 211-212.

55 Zob. X. Zubiri, El hombre y Dios, dz. cyt., s. 170-172.

${ }_{56}$ Zob. X. Zubiri, El hombre y Dios, dz. cyt., s. 204-211; X. Zubiri, El problema filosófico de la historia..., dz. cyt., s. 70-72; X. Zubiri, Naturaleza, Historia, Dios, Madrid 2007, s. 412; M. D. González, Dios, problema de todos, w: Voluntad de vida. Ensayos filosóficos, Seminario Zubiri - Ellacuría, Managua 1993, s. 80.

57 Por. J. Sáez Cruz, La accesibilidad de Dios..., dz. cyt., s. 213-214.

${ }_{58}$ Por. J. Sáez Cruz, La accesibilidad de Dios..., dz. cyt., s. 217. 
samego (de suyo $)^{59}$. On jest rzeczywistością jedną i jedyną. Jest absolutną pełnią „dawania z siebie” (dar de sí). To dawanie siebie sobie samemu jest samoposiadaniem, absolutnym życiem. Bóg jest aktualnością wobec siebie, czyli jest osobą. Posiada inteligencję i wolę ${ }^{60}$. Natomiast $\mathrm{w}$ stosunku do rzeczy jest rzeczywistością fundującą ${ }^{61}$.

Tworząc powyższy szkic, należy pamiętać, że cechy Boga w nim zawarte nie są przyjęte na zasadzie konieczności, ponieważ w doświadczeniu rzeczywistości mamy wieloznacznie zasugerowany kierunek poszukiwań fundamentu. W procesie tworzenia szkicu jesteśmy zatem wolni i możemy przyjąć dowolne inspiracje. W tymże szkicu Zubiri świadomie inspiruje się chrześcijańską wizją Boga ${ }^{62}$.

W powyższych stwierdzeniach, podążając za Zubirim, staraliśmy się racjonalnie wyjaśnić, co mogłoby umożliwić religację ${ }^{63}$. Jednak przeprowadzone do tej pory rozumowanie stanowi jedynie pierwszą - intelektualną (intelectivamente) - część drogi do Boga, którą na podstawie obserwacji, a następnie własnej inwencji przebył intelekt ${ }^{64}$. Przebyty etap rozumowania to element racjonalny drogi do Boga, w sensie angażowania tylko intelektu, który mając bezpośredni, czyli nie poprzedzony żadną teorią, dostęp do religacji, opisuje ją. Następnie intelekt wyciąga wnioski, starając się wyjaśnić religację przez utworzenie jakiegoś szkicu fundamentu ${ }^{65}$. Jednak ten etap nie jest konkluzywny, gdyż religację można wyjaśnić na wiele sposobów, czego dowodem jest historia religii.

\section{Etap rozumowy drogi do Boga}

Drugi etap drogi prowadzącej do poznania Boga wiąże się ze sprawdzaniem, czy szkicowane powyżej pojęcie Boga jest prawdziwe. Jak do

\footnotetext{
59 Zob. X. Zubiri, El hombre y Dios, dz. cyt., s. 149.

60 Zob. X. Zubiri, El hombre y Dios, dz. cyt., s. 187nn.

${ }^{61}$ Por. J. Sáez Cruz, La accesibilidad de Dios..., dz. cyt., s. 218-219.

${ }_{62}$ Por. E. Solari, La raíz de lo sagrado..., dz. cyt., s. 349.

63 Zob. X. Zubiri, El hombre y Dios, dz. cyt., s. 195.

${ }^{64}$ Zob. X. Zubiri, El hombre y Dios, dz. cyt., s. 152, 195.

65 Zob. X. Zubiri, El hombre y Dios, dz. cyt., s. 6.
} 
tej pory, spełnia on wymogi intelektu, bo jest jednym z możliwych racjonalnych wyjaśnień religacji. Niemniej nie mamy pewności, czy jest to prawdziwy obraz Boga, gdyż religacja może być także wyjaśniana choćby panteistycznie, panenteistycznie lub teistycznie, jak to, według Zubiriego, ma miejsce w powyższym szkicu ${ }^{66}$. Jak zatem nabrać pewności, że ten szkic Boga jest prawdziwy?

Jeśli tak naszkicowany obraz Boga jako fundamentu rzeczywistości jest tym, który uzdalnia do życia osobowego, to w celu zweryfikowania jego prawdziwości, obraz ten należy „umieścić” we własnym życiu osobowym. $\mathrm{W}$ ten sposób możemy zweryfikować jego prawdziwość ${ }^{67}$. Zubiri używa tu terminu „doświadczenie” (experiencia) oraz „próbowanie” (probación) ${ }^{68}$.

Weryfikacja szkicu polega na zawierzeniu/poddaniu się (entrega) dającemu się we władzy rzeczywistości (szkicowanemu) Bogu. Tylko w ten sposób możemy w pełni mieć do Niego dostęp. O ile religacja jest dostępem do Boga nierozwiniętym, o tyle zawierzenie jest dostępem pełnym ${ }^{69}$. Zawierzenie to postawa aktywna, w której człowiek akceptuje bycie prowadzonym przez władzę rzeczywistości i stojącego u jej podstaw (ciągle jeszcze domniemanego) Boga, którego obraz naszkicował. Zawierzenie Bogu jest czynnością międzyosobową, w której człowiek daje się Bogu dającemu się w rzeczach. To dawanie się Bogu przejawia się pod różnymi postaciami. Z racji tego, że rzeczy w religacji są ostateczną podporą dla człowieka w jego życiu osobowym, działający w nich Bóg jest tym, któremu należy się cześć, posłuszeństwo, adoracja, dostosowanie moralne. Z tego powodu, że rzeczywistość stwarza możliwości wyboru osobie, Bóg jest tym, do którego możemy zwracać się, prosząc o pomoc w modlitwie. Wreszcie szkic zawiera obraz Boga, który nas pociąga i niejako przymusza

${ }^{66}$ Z pewnością zagadnienie wymaga dyskusji. Por. R. S. Niziński, Panenteísmo en la filosofía de Xavier Zubiri, „The Xavier Zubiri Review” 14 (2016-2108), s. 5-15.

${ }^{67} \mathrm{~W}$ tym miejscu należałoby nawiązać do szczegółów metody Zubiriego i dokonać wprowadzenia, czym są: logos, system referencyjny, rozum, świat, doświadczenie (experiencia), weryfikowanie szkicu. Ze względu na charakter niniejszej pracy nie jest to możliwe. Szczegółowe wyjaśnienie tych terminów można znaleźć w książce Jagłowskiego.

68 Zob. X. Zubiri, Inteligencia y razón, dz. cyt., s. 225-242.

69 Zob. X. Zubiri, El hombre y Dios, dz. cyt., s. 214. 
do ciągłego zajmowania jakiegoś stanowiska wobec rzeczywistości. Dlatego Bóg jest schronieniem i podporą dla człowieka. Postawy te nie są charakterystyczne dla jakiejś religii, tylko są uzasadnioną odpowiedzią na to, co przeżywa się w religacji ${ }^{70}$.

Do momentu utworzenia szkicu fundamentu rzeczywistości był zaangażowany tylko ludzki intelekt. Aby możliwe było zawierzenie, powinna zaangażować się cała osoba ludzka. Potrzeba woli zaakceptowania tego, że Bóg daje mi się w rzeczach, a ja Mu przez to zawierzam siebie. Zubiri mówi tu o swoiście rozumianej wierze $(f e)$ w znaczeniu zawierzenia Bogu jako prawdziwemu, czyli dającemu bycie ${ }^{71}$. Gdy człowiek zatrzymuje się tylko na poziomie poznania, że w rzeczach działa Bóg, ale nie poddaje $\mathrm{Mu}$ się, to wtedy Bóg jest traktowany jako przedmiot. Z czymś takim mamy do czynienia w przypadku teologii i filozofii klasycznej, czyli na przykład w dowodach Tomasza ${ }^{72}$. Tymczasem dla Zubiriego dostęp do rzeczywistości - fundamentu nigdy nie może być tylko czysto intelektualny, bo fundament jest osobą ${ }^{73}$.

Zubiri mówi o woli bycia (voluntad de ser), gdy ma miejsce jedność poznania Boga obecnego $\mathrm{w}$ religacji oraz woli zawierzenia temu Bogu. Wola bycia nie jest zwykłą tendencją, aby być. Jest to przyswajanie sobie konkretnych form rzeczywistości, aby być, gdyż człowiek żyje, konfigurując swoje bycie. Wola bycia jest związana $\mathrm{z}$ wolą prawdy (voluntad de verdad), która sprowadzając się do obecności rzeczywistości w inteligencji, daje całe bogactwo rzeczywistości, czyli jej stałość oraz efektywność realności (patencia, firmeza, efectividad), umacniając tym samym bycie osoby ${ }^{74}$. Woli bycia może być przeciwstawiona wola tworzenia idei (voluntad de verdad de ideas). Człowiek przyjmujący tę drugą postawę nie wchodzi w relację osobową z fundamentem rzeczywistości,

70 Zob. X. Zubiri, El hombre y Dios, dz. cyt., s. 216-218; D. Gracia, El tema de Dios..., dz. cyt., s. 76.

71 Zob. X. Zubiri, El hombre y Dios, dz. cyt., s. 246.

72 Zob. X. Zubiri, El hombre y Dios, dz. cyt., s. 247-248

73 Por. A. Pintor-Ramos, Dios y..., dz. cyt., s. 117.

${ }_{74}$ Zob. X. Zubiri, El hombre y Dios, dz. cyt., s. 258-262; M. D. González, Dios, problema de todos, dz. cyt., s. 80 . 
tylko traktuje go jak przedmiot, nie weryfikując/próbując naszkicowanego obrazu Boga własnym życiu ${ }^{75}$. Zachodzenie zgodności między postulowanym obrazem Boga a moją osobą jest dla Zubiriego istotnym kryterium weryfikowania szkicu Boga. Szkicowany obraz Boga muszę wypróbować w sobie, bo tylko w przypadku religowania mojego Ja do władzy rzeczywistości mam możliwość wglądu od wewnątrz w naturę religacji oraz stwierdzenia, że zachodzi rzeczywista zgodność między naszkicowanym obrazem Boga i jego efektywnym działaniem w moim życiu osobowym ${ }^{76}$.

Gdy człowiek przyjmuje rzeczywistość - fundament (Boga) jako swoją, wtedy pozwala jej się dziać w sobie, czyniąc ją (ten fundament) swoją (swoim). Co więcej, staje się w jakimś sensie podobny do fundamentu (vive en la figura de su fundamento) ${ }^{77}$. Nie należy sądzić, że nawiązanie tego typu intymnej więzi z Bogiem dokonuje się w sposób akonfesyjny. Zubiri zauważa, że jest to możliwe jedynie w ramach jakiejś religii ${ }^{78}$. On sam korzysta z chrześcijańskich inspiracji, szkicując obraz czy też pojęcie Boga, a następnie weryfikuje go także w ramach religii chrześcijańskiej o czym mogą świadczyć cechy relacji człowieka do Boga opisane wyżej oraz choćby to, że ze swoją żoną byli praktykującymi katolikami (oblatami benedyktyńskimi). Potwierdzenie prawdziwości szkicu fundamentu (pewnej hipotezy, czym mógłby być fundament) dokonuje się zatem nie tylko na poziomie intelektu i woli, ale także uczuć, czyli jednym słowem całej osoby ${ }^{79}$. Weryfikacja może być większa lub mniejsza, w zależności od konsekwencji w życiu osobowym, kiedy ulega ono umocnieniu z racji zawierzenia $\mathrm{Bogu}^{80}$. Zawierzenie Bogu nie jest jednorazowym aktem, ale ciągłym stosunkiem (actitud) wobec Niego ${ }^{81}$.

75 Zob. X. Zubiri, El hombre y Dios, dz. cyt., s. 262-269.

${ }_{76}$ Zob. X. Zubiri, El hombre y Dios, dz. cyt., s. 232-233; zob. X. Zubiri, Inteligencia y razón, dz. cyt., s. 215.

77 Zob. X. Zubiri, El hombre y Dios, dz. cyt., s. 269.

78 Zob. X. Zubiri, El hombre y Dios, dz. cyt., s. 235; X. Zubiri, El problema filosófico de la historia..., dz. cyt., s. 83; J. Sáez Cruz, La accesibilidad de Dios..., dz. cyt., s. 214.

79 Zob. X. Zubiri, El hombre y Dios, dz. cyt., s. 224.

80 Zob. X. Zubiri, Inteligencia y razón, dz. cyt., s. 269.

${ }_{81}$ Zob. X. Zubiri, El hombre y Dios, dz. cyt., s. 271. 
Są różne formy weryfikacji naszkicowanego obrazu Boga, polegające na jego „fizycznym próbowaniu” we własnym życiu. Jedną z form próbowania, weryfikacji jest „współprzenikanie” (compenetración). Tego typu doświadczenie polega na pozwoleniu, aby Bóg - zakładając, że jest osobą dającą się innym osobom - mnie przenikał. Przykładem takiego współprzenikania jest historia Izraela, gdy naród ten powierza się Bogu w ciągu swojej historii i jednocześnie doświadcza potwierdzenia, że Bóg rzeczywiście działa, gdyż interweniuje w jego historii, chroniąc go, czyli umacniając życie osobowe poszczególnych jednostek. Zubiriemu chodzi zatem o osobiste doświadczenie działania Boga. Stwierdza wręcz, że Bóg jest „,moim” Bogiem ${ }^{82}$. Innym rodzajem doświadczenia jest „upodobnienie” (conformación). Polega ono na tym, że umieszczam w mojej rzeczywistości szkic możliwości, które wynikają z tego, kim jestem lub mogę być, gdy Bóg jest taki, jak Go szkicuję. W przypadku szkicu fundamentu rzeczywistości zarysowanego wcześniej mogę przyjąć, że jestem boską donacją (donación divina) ${ }^{83}$.

Człowiek, powierzając się Bogu, powinien doświadczać tego, czego nie doświadcza ten, kto się Bogu nie powierza (jeśli szkicowany obraz Boga jest prawdziwy). W tym zawierzeniu, stwierdza Zubiri wprost, człowiek otrzymuje pewne poznanie Boga i światło przekraczające możliwości jego osobistej inteligencji ${ }^{84}$. Być może nie byłoby nadinterpretacją wobec myśli Zubiriego stwierdzenie, że Bóg „mistycznie” potwierdza człowiekowi to, że jest, i jaki jest ${ }^{85}$. Innymi słowy, Bóg ma być tym, który w doświadczalny sposób nie tylko umacnia moją osobę, i to bardziej niż w przypadku innych weryfikowanych szkiców Boga, ale i ją od wewnątrz poucza ${ }^{86}$. Wtedy też szkicowany obraz Boga jest dowiedziony, będąc koniecznym, a nie dodatkowym elementem tworzenia mojej osoby ${ }^{87}$.

${ }^{82}$ Zob. X. Zubiri, Inteligencia y razón, dz. cyt., s. 249-251; X. Zubiri, El hombre y Dios, dz. cyt., s. 121.

83 X. Zubiri, Inteligencia y razón, dz. cyt., s. 254-257; J. Sáez Cruz, La accesibilidad de Dios..., dz. cyt., s. 220-221; F. Llenín Iglesias, La realidad divina..., dz. cyt., s. 95.

84 Zob. X. Zubiri, El problema filosófico de la historia..., dz. cyt., s. 82-83.

85 Oczywiście chodzi o mistykę naturalną: R. S. Niziński, Zubiri como místico, „The Xavier Zubiri Review” 14 (2016-2018), s. 73-85.

${ }^{86}$ Por. A. Pintor-Ramos, Religación y..., dz. cyt., s. 331.

87 Zob. X. Zubiri, El hombre y Dios, dz. cyt., s. 202. 
Po dokonaniu powyższych analiz bardziej zrozumiałe jest stwierdzenie Zubiriego, że optowanie za Bogiem - fundamentem jest racjonalne (razional). To intelekt odkrywa, że są ku temu zawierzeniu podstawy wypływające z religacji. Jednak już zawierzenie Bogu nie należy do sfery racjonalnej, ale sfery, która jest dalszą konsekwencją racjonalności, bo to wola decyduje, czy wejść w intymną relację z tak naszkicowanym Bogiem, powierzając Mu całą osobę. Zawierzenie jest rozumne (razonable). Zależy ono od osobistej postawy, czyli oprócz intelektu angażuje wolę i uczucia. Człowiek chce swoje życie osobowe umocnić przez przylgnięcie do źródła rzeczywistości. Zubiri mówi nawet o miłości do Boga, jako formie przylgnięcia do Niego. Miłość jest jednym z warunków weryfikacji obrazu Boga ${ }^{88}$. Dlatego Zubiri może powiedzieć, że rozumność to coś więcej niż racjonalność ${ }^{89}$. Racjonalny obraz Boga to obraz wyjaśniony przez intelekt, a rozumny to godny zaufania, bo wypróbowany we własnym życiu ${ }^{90}$. Rozumny to także taki, który nie jest doskonale zgodny z rzeczywistością (bo byłby wtedy racjonalny), ale z nią zbieżny, czyli będący pewną konsekwencją racjonalności. Jest zbieżny z kierunkiem, który sugeruje rzeczywistość ${ }^{91}$. Należy to rozumieć w ten sposób, że percypowana rzeczywistość sugeruje człowiekowi pewną drogę poszukiwań fundamentu.

Dlatego, podsumowując, przestawiona przez Zubiriego koncepcja drogi poznania Boga nie wykazuje istnienia i natury Boga wprost, lecz wskazuje jedynie na to, że w tym, co jest dane (sposób tworzenia Ja), jest coś, co można nazwać Bogiem (są nim cechy fundamentu rzeczywistości pozwalające jej tworzyć Ja) ${ }^{92}$. Dlatego jest to poznanie demonstratywne, czyli istnieją pewne przesłanki na poziomie poznania intelektualnego, że coś takiego jak Bóg może istnieć ${ }^{93}$.

88 Zob. X. Zubiri, El problema filosófico de la historia..., dz. cyt., s. 257.

89 Zob. X. Zubiri, El hombre y Dios, dz. cyt., s. 276-277, 434-435.

90 Zob. X. Zubiri, El problema filosófico de la historia..., dz. cyt., s. 283.

91 Zob. X. Zubiri, El problema filosófico de la historia..., dz. cyt., s. 283; M. D. González, Dios, problema de todos, dz. cyt., s. 81-84.

92 Por. A. Pintor-Ramos, Religación y..., dz. cyt., s. 227.

93 Zob. X. Zubiri, El hombre y Dios, dz. cyt., s. 246-247. 
Zubiriego droga religacji nie jest drogą, która zmierza drogą pojęć greckich, jak ma to miejsce w filozofii Tomasza $\mathrm{z}$ Akwinu, bo jest argumentem z życia osobowego człowieka ${ }^{94}$. Jest „próbą” we własnym życiu osobowym $^{95}$. Człowiek niejako we własnym życiu przekonuje się, że przyjęta przez niego hipoteza, kim miałby być Bóg, jest prawdziwa. Potwierdzony w zawierzeniu szkic Boga jest czymś więcej niż tylko pojęciem, gdyż okazuje się być rzeczywistą zasadą mojego życia osobowego. A to umożliwia tak „dowiedzionemu” Bogu bycie jednocześnie Bogiem religii.

Zgodnie z metodą Zubiriego ostatnim krokiem jest zrozumienie rzeczywistości z perspektywy poznanego już fundamentu. Dokonuje się to przez powrót do rzeczy z perspektywy tego, czym ta rzecz ,jest realnie”, to znaczy, gdy już wiemy, czym jest fundament rzeczywistości. Jest to zobaczenie, jak Bóg jako fundament rzeczywistości wpływa na to, czym są rzeczy, oraz jak ja tworzę Ja w oparciu o rzeczywistość $c^{96}$. Jest to wyjaśnienie enigmatyczności władzy rzeczywistości tworzącej Ja. Zubiri dochodzi do wniosku, że każda rzecz jest własną rzeczywistością i jednocześnie czymś ufundowanym w Bogu. Każda rzecz jest donacją osobową Boga. Bóg jest transcendentny w rzeczach. Jest on osobowym fundamentem wszystkich rzeczy, które przenoszą Jego moc. Bez Niego rzeczy nie byłyby w stanie determinować Ja, bo byłyby pozbawione realności. Natomiast Bóg sam (w sobie) jest rzeczywistością absolutnie absolutną ${ }^{97}$. Jest dawaniem się sobie samemu. Gdy zechce, daje się także rzeczywistości w stosunku do Niego zewnętrznej. Rzeczy i człowiek są Bogiem ad extra ${ }^{98}$.

Zubiri dystansuje się wobec swojej metody, choć uważa ją za bezwzględnie konkluzywną. Owszem, udaje mu się wyjaśnić problem tworzenia ludzkiego Ja, niemniej stwierdza, że jego własny szkic Boga, choć

94 Zob. X. Zubiri, El hombre y Dios, dz. cyt., s. 168-169; M. D. González, Dios, problema de todos, dz. cyt., s. 79, 82; A. Pintor-Ramos, Religación y..., dz. cyt., s. 323; M. Jagłowski, Realizm transcendentalny..., dz. cyt., s. 225-227.

95 Zob. X. Zubiri, El hombre y Dios, dz. cyt., s. 246-247.

96 Zob. X. Zubiri, Inteligencia y razón, dz. cyt., s. 336-337.

97 Por. J. Sáez Cruz, La accesibilidad de Dios..., dz. cyt., s. 222; A. Pintor-Ramos, Dios y..., dz. cyt., s. 113.

98 Zob. X. Zubiri, El hombre y Dios, dz. cyt., s. 478. 
potwierdzony w doświadczeniu, nie jest ostatecznym rozwiązaniem problemu religacji, gdyż ostatecznego rozwiązania nie ma. Poznanie fundamentu rzeczywistości jest jedynie marszem ku prawdzie, bo do prawdy jedynie się przybliżamy. Można najwyżej mówić o zachodzeniu zbieżności szkicu fundamentu w stosunku do tego, co jest dane w procesie tworzenia $\mathrm{Ja}^{99}$. Zubiri w ramach swojej drogi dochodzi do wniosku, że to chrześcijański obraz Boga najlepiej wyjaśnia omawiany tu problem tworzenia Ja, choć jest to rozwiązanie prowizoryczne ${ }^{100}$. Takie postawienie sprawy wiążę się ze wspomnianą wyżej teorią prawdy (racjonalnej) Zubiriego, która mówi tylko o zbieżności szkicowanego obrazu Boga, a nie o jego całkowitej zgodności z rzeczywistym fundamentem ${ }^{101}$. Dlatego prawdziwość szkicu w tym dowodzie jest stopniowalna. Zweryfikowane pozytywnie obrazy Boga mogą być bardziej lub mniej prawdziwe, a także fałszywe - w zależności od stopnia zbieżności ${ }^{102}$.

\section{Uwagi krytyczne i kwestie problemowe $\mathrm{e}^{103}$}

1. W „dowodzie” Zubiriego kryterium weryfikacji szkicu jest podwójne: (a) więź ze (szkicowanym) Bogiem przeżyta w zawierzeniu Mu (w ramach jakiejś religii) musi doświadczalnie potwierdzać mnie jako osobę w całości w dynamicznym rozwoju tej osoby oraz (b) szkicowany obraz Boga (któremu zawierzyłem) powinien umożliwiać i wyjaśniać religację.

99 Zob. X. Zubiri, El hombre y Dios, dz. cyt., s. 280-281; zob. X. Zubiri, Inteligencia y razón, dz. cyt., s. 262-264.

100 Zob. X. Zubiri, El hombre y Dios, dz. cyt., s. 15; por. A. Pintor-Ramos, Dios y..., dz. cyt., s. $115-116$.

101 Zob. X. Zubiri, Inteligencia y razón, dz. cyt., s. 264; X. Zubiri, El problema filosófico de la historia..., dz. cyt., s. 155.

102 Zob. X. Zubiri, El problema filosófico de la historia..., dz. cyt., s. 156-157; X. Zubiri, Inteligencia y razón, dz. cyt., s. 258, 270; J. Sáez Cruz, La accesibilidad de Dios..., dz. cyt., s. 194; A. Pintor-Ramos, Dios $y \ldots$, dz. cyt., s. 114-116.

${ }_{103}$ Kwestia metody, jaką posługuje się Zubiri, jest tematem szczegółowo przezeń analizowanym, toteż nie sposób go tutaj ani zrelacjonować, ani się do niego ustosunkować, bo wymagałoby to przynajmniej dodatkowego artykułu. Tutaj została ona przedstawiona tylko skrótowo, po to, aby móc wejść w samą istotę „dowodu” Zubiriego. 
O ile drugie kryterium jest jasne, o tyle pierwsze sprawia pewne trudności. Antonio Pintor-Ramos stwierdza, że jeśli ludzkie życie w świetle tak naszkicowanego fundamentu, umieszczonego w życiu osobowym, jest bogatsze i prawdziwsze niż w innych przypadkach, to w tym wypadku zostaje potwierdzone, że tak szkicowany fundament należy rozumieć jako Boga, gdyż Bóg dla Zubiriego jest tym, który daje człowiekowi pełnię bycia (ser) i życia ${ }^{104}$. Wiemy jednak, że metoda Zubiriego wymaga potwierdzenia prawdziwości szkicowanego obrazu Boga we własnym wnętrzu osoby w kontekście religijnym, a przecież każdy wyznawca w ramach swojej religii ma potwierdzenie prawdziwości własnego religijnego obrazu Boga.

W związku z tym rodzi się pytanie, jak na podstawie wewnętrznego doświadczenia można ocenić stopień zgodności weryfikowanego szkicu (obrazu) Boga z tym, kim jestem? Problematyczność tego kryterium daje się zauważyć w rozważaniach Enzo Solari na temat prób oceny prawdziwości poszczególnych religii. Próby te kierują się podobnymi kryteriami, jak przy drodze prowadzącej do filozoficznego poznania Boga. Solari uznaje, że Zubiri przyjmuje kryterium historyczne jako najpewniejsze w weryfikacji zachodzenia prawdy religijnej, i to w tym kryterium umieszcza także kryterium indywidualnego potwierdzenia prawdziwości szkicu. To ludzka historia konstytuowana przez indywidua i społeczności jest tą, która pozwala zweryfikować to, co oferują poszczególne drogi religijne. Solari uznaje, że dla Zubiriego, przynajmniej w niektórych jego wypowiedziach, to historia religii, jako jedyny możliwy trybunał, stwarza możliwość oceny realizowania się szkiców religijnych oraz pozwala stwierdzić, czy obraz Boga proponowany przez jakąś religię można przyjąć za prawdziwy ${ }^{105}$. Na podstawie tej wypowiedzi Solariego można odnieść wrażenie, że sam Zubiri poszukiwał obiektywniejszego kryterium weryfikacji prawdziwości szkicu niż indywidualne odczucie ubogacenia własnego życia osobowego.

104 Zob. A. Pintor-Ramos, Religación y..., dz. cyt., s. 331.

105 Zob. E. Solari, La raíz de lo sagrado..., dz. cyt., s. 360. Powołuje się on na: X. Zubiri, El problema filosófico de la historia..., dz. cyt., s. 206-207, 362-363. 
2. Zubiri zarzuca Tomaszowi, że w doświadczeniu tworzenia bytów nie mamy do czynienia z przyczynowością, lecz jedynie z następstwem zdarzeń, stąd mówienie o przyczynie i skutku jest już teorią. Czy rzeczywiście, jak chciałby tego Zubiri, intelekt w doświadczeniu religacji ma bezpośredni dostęp do natury wpływu rzeczywistości na osobę? Czy jest faktem, że gdy rzeczy pojawiają się w mojej świadomości, to ta przyjmuje nowy stan (nową formę bycia)? Zubiri, odrzucając możliwość bezpośredniego poznania natury zależności między rzeczami w doświadczeniu zmysłowym (co umożliwia mu odrzucenie dowodów Tomasza), znajduje taką możliwość w procesie tworzenia Ja, gdyż bezpośrednim świadkiem tego tworzenia miałby być intelekt. Czy jednak i w tym momencie nie popadamy już w jakąś teorię? Dlaczego tego typu poznanie jest pewniejsze niż doświadczenie zmysłowe i towarzyszące mu przekonanie, że rzecz tworzy rzecz? Stąd pierwszy zarzut wobec Tomasza nie do końca wydaje się przezwyciężony w ramach metody proponowanej przez Zubiriego, gdyż on sam wprowadza tu własną teorię.

3. Czy jest faktem, że rzeczy są niezbędnym elementem tworzenia Ja? Według filozofów dialogu jedynie osoba w relacji osobowej z inną osobą ma wobec niej funkcję osobotwórczą. Obecność rzeczy w świadomości umożliwia jej jedynie funkcjonowanie świadomościowe (psychiczne), ale nie osobowe ${ }^{106}$.

4. Dlaczego tylko bycie czymś ostatecznym, a nie na przykład stwarzającym z nicości albo bytem koniecznym, ma świadczyć o byciu Bogiem? Czy rzeczywistość posiadająca te dwie ostatnie cechy nie może być podstawą do nawiązania $\mathrm{z}$ nią relacji religijnej? W pytaniu tym chodzi o to, czy relacja religijna jest możliwa jedynie z takim Bogiem, który umożliwia moje życie osobowe? Otrzymany przez Zubiriego obraz Boga ukazuje Boga przede wszystkim mojego życia osobowego. Pytanie, czy to wystarczy.

Wracając do pytania postawionego na wstępie, można się zgodzić, że obraz Boga zaprezentowany przez Zubiriego jest zgodny z tym, jak Boga rozumie filozofia oraz religia. Pozostaje jednak kwestią wątpliwą, czy przedstawiona przez Zubiriego metoda poznania Boga może być

106 Por. M. Buber, Słowa-zasady, tłum. K. Bukowski, „Znak” 26 (1974) nr 3, s. 291-300. 
wykorzystana poza jego systemem filozoficznym opartym na dyskusyjnym pojęciu religacji.

\section{Bibliografia}

Augustyn z Hippony, O wolnej woli, tłum. A. Trombala, w: Augustyn z Hippony, Dialogi filozoficzne, Kraków 1999, s. 493-649.

Buber M., Słowa - zasady, tłum. K Bukowski, „Znak” 26 (1974) nr 3, s. 291-310.

Díaz Muńoz G., Búsqueda de Dios en el misterio según X. Zubiri, „Estudios Eclesiásticos” 84 (2009) núm. 328, s. 131-162.

Ferraz Fayos A., Zubiri: el realismo radical, Madrid 1988.

González M. D., Dios, problema de todos, w: Voluntad de vida. Ensayos filosóficos, Seminario Zubiri - Ellacuría, Managua 1993, s. 77-91.

Gracia D., El tema de Dios en la filosofía de Zubiri, „Estudios Eclesiásticos” 56 (1981) núm. 216-217, s. 61-78.

Hartshorne Ch., Man's Vision of God and the Logic of Theism, Connecticut 1964.

Jagłowski M., Realizm transcendentalny Xaviera Zubiriego, Olsztyn 2000.

Janka F. T., Jana Dunsa Szkota dowód na istnienie Boga, w: Primum philosophari. Opuscula Antonio Siemianowski dedicata, Poznań 2016, s. 115-132.

Jędraszewski M., Bóg filozofów i Bóg Jezusa Chrystusa, Poznań 2011.

Kant I., Krytyka praktycznego rozumu, tłum. J. Gałecki, Warszawa 1972.

Llenín Iglesias F., La realidad divina. El problema de Dios en Xavier Zubiri, Oviedo 1990.

Niziński R. S., Panenteísmo en la filosofía de Xavier Zubiri, „The Xavier Zubiri Review” 14 (2016-2018), s. 5-15.

Niziński R. S., Zubiri como místico, „The Xavier Zubiri Review” 14 (2016-2018), s. 73-85.

Pintor-Ramos A., Dios y el problema de la realidad en Zubiri, „Cuadernos de Pensamiento” 1987 núm. 1, s. 107-121.

Pintor-Ramos A., Religación y “prueba” de Dios en Zubiri, „Razón y Fe” 218 (nov. 1988) núm. 1081, s. 319-336.

Potępa M., Obraz człowieka w hermeneutyce Schleiermachera, „Analiza i Egzystencja” 19 (2012), s. 113-132.

Sáez Cruz J., La accesibilidad de Dios: su mundanidad y transcendencia en X. Zubiri, Salamanca 1995. 
Solari E., La raíz de lo sagrado. Contribuciones de Zubiri a la filosofía de la religión, Santiago de Chile 2010.

Thomae Aquinatis, Summa theologiae, pars I, Matritii 1978.

Zubiri X., El hombre y Dios, Nueva edición, Madrid 2012.

Zubiri X., Naturaleza, Historia, Dios, Madrid 2007.

Zubiri X., Inteligencia y razón, Madrid 2008.

Zubiri X., Inteligencia y logos, Marid 2008.

Zubiri X., Inteligencia sentiente, vol. 1: Inteligencia y realidad, Madrid 2011.

Zubiri X., El problema filosófico de la historia de las religiones, Madrid 2006.

\section{Abstrakt \\ Racjonalność czy rozumność: próba zmiany paradygmatu filozoficznego poznania Boga - myśl Xaviera Zubiriego}

Znaczna część filozoficznych dowodów na istnienie Boga oraz innych prób mówienia o Nim stara się sprostać jedynie kanonom racjonalności, tym samym raczej wyklucza dojście do takiego obrazu Boga, który może być Bogiem religii. Zubiri stara się przedstawić taką filozoficzną drogę do Boga, w wyniku której otrzymany obraz Boga będzie jednocześnie Bogiem religii. Wymaga to jednak częściowego odejścia od racjonalności na rzecz rozumności, gdzie rozumność to zgodność z życiem człowieka.

\section{Słowa kluczowe}

osoba, osobowość, religacja, władza rzeczywistości, doświadczenie

\section{Abstract \\ Rationality vs Reasonableness of the Philosophical Way to God. The Thought of Xavier Zubiri}

The majority of the philosophical proves of the existence of God or other philosophical attempts of talking about Him try to meet standards of rationality only. In this way they reach mostly a philosophical notion of God which rules out a religious relationship to Him. Zubiri is trying to present a philosophical way which leads to a notion of God, 
who can be at the same time a God of philosophy and of religion. But this means overcoming rationality with reasonableness. Reasonable means compatible with human life.

\section{Keywords}

person, personality, religation, power of the real, experience 